\title{
THE DOCTRINE OF THE RESURRECTION OF THE BODY IN THE THEOLOGICAL THOUGHT OF THOMAS BURNET
}

\author{
CIPRIAN SIMUȚ* \\ Partium Christian University, Oradea, Romania
}

\begin{abstract}
The issue of the resurrection of the body has given rise to a plethora of interpretations. There is a natural need to clarify such issues, since there cannot be a separation between faith in Christ and the resurrection of the body. The two go hand in hand, because one cannot go without the other. In the context of debates spawned by the need to understand, Thomas Burnet seems like a study theologian and a clean hearted man, who wrote for the neighbour, and who managed to offer a detailed map of the resurrection the body. The essay will point to the main aspects of the Burnet's theology on the resurrection of the body, in a rather descriptive manner. It will also refer to other writers, who tackled the same issues, as a means to show the depth of Burnet's perspective.
\end{abstract}

KEYWORDS: resurrection, body, Burnet, redeemer, restoration

\section{Introduction}

The issue of the resurrection of the body has been addressed throughout the history of Christian thinking. As the scientific methods developed, so did those of philosophy and logic. Each writing reflects its own time and prejudices, revealing specific characteristics. At one point, during the 19th century, it was proposed that if science develops in time, so should the reflection on the doctrine of bodily resurrection of the dead. As in science, the ideas and theories change naturally, since knowledge expands. This should be the case for such a dogma as well. After the 16th century, the doctrine of the resurrection was explained in a scientific manner, for better or for worse, but the attempts seem to be out of pure scientific interest, even if the subject is characteristically Christian. The length to which the argumentation process is taken, shows the keen interest of these theologians to be of use to the readers. There seems to be a practical purpose behind

* CIPRIAN SIMUȚ (PhD 2012, Babeș-Bolyai University, Cluj-Napoca) is a research collaborator at the Partium Christian University, in Oradea, Romania. E-mail: ciprisimutid@gmail.com. 
the books and articles on the resurrection, namely to ease the understanding of this difficult doctrine for the general public.

Tackling the issues of the resurrection might seem uninteresting for the modern man, and dismissed as myth, but for the 18 th century reader it must have been quite entertaining and useful. Burnet was not an every-day Anglican. He was deemed heterodox, due to his views on the creation. He had deistic influences, and he was one the of the first to develop a historical view of creation. He paid the price for his views, in ecclesiastical circles. Nevertheless, he continued to publish books on subjects which became the rage almost two centuries later.

In this context, the essay is descriptive, choosing to present the thinking of Burnet, rather than going about finding points of divergence with other writers. There are references to other writers, but the purpose is to identify some of the main ideas in Burnet's reasoning, since he was not only a theologian, but also a scientist. His analytical take on the issue of the resurrection proves his fascination with the scientific methods and logical argumentation.

\section{What Is a Resurrected Body}

Chapter VII of Burnet's book deals with the issue of the resurrection and the state of the resurrected bodies after the event. Burnet considers this issue to be of utmost importance, because it deals with the issue of dead people and their bodies in various stages of decomposition, up to the event of their resurrection. When he tackles the issue, Burnet acknowledges that both Jews and non-Jews, namely Gentiles, have doctrines connected to issues such as the future and the resurrection. However, they are confusing and sparse. If the non-Jews, in general, argue for a resurrection that included all of mankind, the Jews learned nothing about the resurrection, nor the immortality of the soul, at least not from the writings of Moses. He makes a bold indirect conclusion, stating that Moses and the Sages must have known about such matters, even if they were confined to the just and the Israelites. Even more so, their view on the resurrection was limited to a terrestrial, not a celestial one. The doctrine of salvation and the resurrection was, eventually, described by the Old Testament writers, but not at length, and never in a clear, final manner. The final version of the doctrine was established through the teachings of Jesus Christ (Burnet 1739: 180).

There is a connection between Christ's resurrection and the resurrection of the dead (Bush 1845: 14-16), namely that the second cannot happen without the first, and if the first is believed, then the second must be believed as well. Furthermore, if Christ is the Head of the body, the body cannot lay in the grave forever. If Christ is Judge, the ones to receives 
judgement must rise from death and be alive. Lastly, if the resurrection is false, the entire Gospel is meaningless, so it follows that the preaching, faith, and redemption are without meaning as well (Felton 1725: 2).

Burnet's vision of the resurrection is overwhelming, and it has hyper-victorious ring to it. He presents the clear reason for which Christians should be joyful, namely the victory of Christ over Death and the infernal world. Through His victory, which came, paradoxically, in His death, the Christians are triumphant. They are triumphant not through their own strengths, as if some effort must be done in order to gain victory. However, the Christians are still living in a decrepit world, subdued by death and evil. In this vile 'dunghill', Christians live and 'converse', wearing the human body as a coarse cloth and a carcass. The sinful world is contrasted with the restoration to Light and the enjoyment of blissful immortality, together with the brightness of aethereal regions, where the resurrected believers would enjoy 'endless ages happy' (Burnet 1739: 182). The current world is nothing less than an infernal one, making no mistake over the spiritual issues that men and women face daily. Life for the Christian is not easy, nor is it in any way joyful. The reason for happiness is the understanding that Christ has won and that there is an assurance of the good things to come at His return. However, enjoying one's life on Earth is not an option, nor a possibility, when it is contrasted with the maleficent and vile actions of humans. In the context of the future resurrection of the body and the promises of Christ regarding the future state of the believers, Burnet encourages them to cleanse themselves of all 'filthiness of the flesh and spirit', and to perfect their holiness, through the fear of God (Burnet 1739: 182-183).

At this point, Burnet turns to the biblical passages that his readers should know in order to separate from the evils of the world and point their attention and hope on the risen Christ. He mentions Christ talking about men who would be risen from the dead. This resurrection would happen due to the power inherent to Christ, and through His will. This is possible not only because Christ is the Lord of Life, but He is also the Lord of Death. Consequently, both realms are under His complete power. In classic Christian doctrine, Christ proved His power over both life and death, in the act of His own resurrection. Had He not raised Himself from the dead, all His words and teachings on such matters would have been utter nonsense (Bush 1845: 104). On this idea, Christ goes further promising rewards for those who aided the needy, the poor, and the infirm. These categories cannot repay the good and the goods they had received. Therefore, those who helped them are due their just reward. However, the other category of just who will receive even more, at their second birth, or their resurrection, are the disciples and all who forsook their families and worldly possessions, 
in order to follow Christ. Having mentioned these two categories, Burnet argues further that the power of Christ will be manifested in His words, and that it will be His command that will raise them from the dead. Burnet makes an important point because the issue of the resurrection of the dead is intrinsically connected to the very essence of Christ, the Redeemer, who gave His life, but also came back to life. The capacity of Christ to come back to life, in a glorified body, puts Him above and beyond any other human being, because none have such power (Burnet 1739: 185). In the case of Christ, He was fully aware of the power He was wielding, since He had already taught His disciples and His hearers about the resurrection of His own body. This power was attested, eventually, when the event had taken place, and by the following showings of Christ to His disciples, until the time of His ascension (Burnet 1739: 185-186).

The image of the resurrected body connects the soul to the flesh and blood. At times they are described as being complete opposites, but that they are also complementary, while in other writings, they are interdependent. While the body is alive, the soul would thrive, but the body acts as an obstacle on the path of spirituality. The soul must constantly look at the body and manage its sluggishness. The soul cannot perceive the spiritual reality to the best of its abilities, and it cannot act in the manner it desires. In order to be in full submission to God, the body must be resurrected. While on earth it cannot thrive, because of its sinful naturefound in flesh and blood, so it follows that the only way the human being can ultimately be connected to God, is through the resurrection.

Christ is described as a wielder of a power that, not only allowed Him to die and rise from the dead, but also to disappear, when He desired to flee His enemies. Also, Christ appears to have used this power when $\mathrm{He}$ confronted His enemies, on other occasions, and it made Him look so radiant, that His foes became awe-struck and terrified. In these two instances it seems that Burnet projects onto Christ a kind of powermanipulation that made Him the stuff of myth and legends. As for Christ's transfiguration, Burnet adds an element that takes the image into the realm of fantasy. If the Bible simply describes the appearance of Christ as one possessing a body which was as bright as the sun, and whose clothes were pure light, Burnet adds the image of 'vital Flame' (Burnet 1739: 187). This image depicts the perfection of Christ with a new element, which is not mentioned as such in modern descriptions of the event, in sermons, for example. Christ kept His body in a physical form, despite having access to divine power or being raised from the dead (Bush 1845: 156).

However, for Burnet the transfiguration points to the idea that Christ proved He had life and that He was life. He did not win over death only on the cross, since He is an all-powerful God, but he showed His disciples that 
He had the power over life, death, mortality at his disposal at all times. By bringing down Moses and Elijah, Christ showed that His power was over all creation and that human beings do not finish their existence in death but live beyond it. His power also showed the apostles a glimpse of the things to come, of the future state (Burnet 1739: 188). The event of the transfiguration is significant for both Christ and the apostles, because it signals that the Kingdom of Christ was in the world, and He was the key to enter it. He was not a mere messenger, but the Life. The apostles saw, empirically, within the limits of their bodies, that Christ is who He has always said to be. There should have been no doubt as to what He had to do. However, despite the proofs the apostles received, their humanity was overwhelmingly limited, evaluating the situation in a manner that showed how impossible it was for a finite being to comprehend the limitless power of Christ.

The resurrection of Christ and man is not limited only to the reasons pertaining to the reward man would get. As man develops a set of values, he will enact them in daily life. Actions will have consequences, but not all of them take place while man is alive. God does not enact His full justice while men are on Earth, in the human body. The definitive act of His justice will take place after the resurrection of the bodies of all human beings. That resurrection is connected to and demanded by the moral and retributive justice of God. It can be argued that once physical death occurs, spiritual life continues, but the question is whether this continued life is connected to the deeds done while men were alive. Some would argue that the consequences of men's actions are eternally valid. Therefore, a resurrection is needed, or demanded by the very essence of God, who would do justice to all (Drew 1811: 131).

The ascension is the next event that proved, together with the transfiguration and resurrection that the apostles and all believers would inherit the eternity that Christ had won for them, in His body, ministry, and life. Burnet argues that through the ministry of Christ, the resurrection is certain, established, and unchangeable. The seal and guarantee are Christ himself, and the beneficiary are the believers. He does make sure that the issue of the resurrection is understood by his readers as enacted by a power that is divine, not natural. He assumes that the human body has no capacity, in itself, to generate, possess, administer, or receive such power. The event of the bodily resurrection is completely dependent on the involvement of God Himself. There is a link between the death and the resurrection of Christ, since Burnet argues that the apostle Paul described Christ as the essence and foundation of Life and Adam as the essence and foundation of death, since through his sin, God intervened through Himself, not another being, to solve the issue of men's bodily and spiritual death. In this context, 
Burnet makes the point that death has been under Christ's control since the beginning, but in His humanity, He conquered death through His own death and resurrection, but the final victory over death will be at the moment of universal resurrection. It means that both righteous and unrighteous will benefit from the resurrection, an event in which the Trinity is involved in a harmonious cooperation (Burnet 1739: 192-93).

Burnet pushes the discussion further, by addressing the issues of the type of body the resurrected will have. He refers to 1 Corinthians 15:35. Burnet begins by pondering on whether the resurrected body will be organic, 'gross and closely compacted' or 'thin, loose, and a light one, resembling air of aether' (Burnet 1739: 194). The issue must be dealt with in terms of form, as well as matter, but beginning from the revelation found in the Bible, not just parts of it. In this context, Burnet identifies four 'characteristical tokens' of the resurrected body. First, the body will not have internal organs; second, it will have no flesh and blood; third, it will not be made with hands, and fourth, it will be like the bodies of the angels. He concludes that for the first issue, based on 1 Corinthians 6:13, the only conclusion is that God will make the body without the digestive system, only after the resurrection. Further in his argument there is a consequence in his line of thinking, namely that since the hands and the feet are used only to touch, walk, and manipulate substances that are immovable, they are not of any use, since the heavens and the aethereal are not based on solid matter, it follows that the bodies will float, fly, or move without the use of limbs, just like the angels'. The issue of the body is more complex, once Burnet explains that since food is no longer used after the resurrection, there must be severe modifications to the glorified body, such as the loss of 'the organs of taste, chewing and swallowing; organs of concoction, of sanguification, and those of distribution; and not a few of the glands are useful to nutrition or secretion' (Burnet 1739: 196).

The issue of whether the same body or another body would be resurrected (Bush 1845: 166), is also connected to the principle that there are elements, particles, in the human body, that are connected to the soul. These particles seem to be connected even after the body is laid in the grave. On the same note, the argument goes in favor of the resurrection of the very same body that was laid in the grave (Bold 1706: 2). There are limits to any of these arguments, especially, when the idea of a completely new body, which has an identity of personhood in the soul and mind of the believer, and an identity in Christ's body, in relation to the resurrection.

After the issue of the organs, Burnet goes to the issue of the blood and flesh, as mentioned by the apostle Paul in 1 Corinthians 15:50. He observes a state of non-compatibility, of 'repugnancy', between the glorified state of the body and its earthly state. They cannot coexist. It seems as one must 
give way to the other. Burnet also addresses the issue of the symbolic interpretation of 'flesh' and 'blood', but he argues that there is no proof this would be the case. Such an argument would also go against the principle of literal interpretation, which is paramount for Burnet. The logic of the entire text is so well knit together in the Biblical text, thar Burnet believes there is no reason to contradict it, or to impose a 'mystical' or symbolic interpretation (Bush 1845: 259). Flesh and blood must be physical, just as the connection of the word 'corruption' as referring to the corruptible body. The flesh can only be corruptible, and Paul nowhere mentions that the flesh could be otherwise. The logical conclusion follows, namely that if physical flesh and blood can only be corruptible, and there is no other kind, then flesh and blood cannot inherit Heaven (Burnet 1739: 199-200).

The human body and the celestial body are essentially different; however, Burnet identifies an interesting similarity. He addresses 2 Corinthians 5:1 and argues that 'not made with hands' is a common trait of both human and celestial realms. This is so because the human being is created from 'liquid seed' and 'from a minute drop', which transforms into 'greater mass, and to an admirable frame'. The development is due to a 'force internal', which is not assisted by any hand. In other words, human hands do not contribute through their skills to the making of a new human being. It is all assisted by God and the internal 'force' (Burnet 1739: 200201). Even if the celestial bodies are natural, they are still different in their makeup. The human body remains organic, because it is made of matter which has the form and characteristics of the specific human organs. The celestial body, on the other hand, cannot have any organic structure, since, as mentioned before, it will not have any internal organs. Therefore, the glorified body will be inorganic (Burnet 1739: 201).

Burnet also believes that in Luke 20:35-36, Christ tells His hearers that the resurrected body will be as that of the angels. The similarity does not refer only to the marital status of the resurrected, but also to the characteristics of the celestial bodies. He underlines the idea that since angels have bodies, and the future bodies of the resurrected will be like theirs, it follows that there will be a certain kind of bodies. Furthermore, the similarity also argues in favor of the immortality of the resurrected bodies. There will be no death for them. In fact, Burnet mentions that the human soul is immortal, before any resurrection would take place. The issue was whether the immortality refers to the body or the soul. Therefore, Burnet believes that the similarity that Christ mentions, is not in reference to soul, but to the body. Besides, the bodies of the angels need to be, by necessity, not 'naked spiritual substances, but cloathed with bodies of their own kind and order'. This is due to their specific job description, namely, to attend to and guard Christ, including the time of His 'glorious coming'. This is 
necessary because they need to be seen on that day, but they also need to represent the majesty and the glory of Christ (Blomfield 1828: 327). These bodies are their own and have been theirs since their beginning. Angels will not have bodies only for the event of the Second Coming, theirs will only become visible. He also points out that, when Christ talks about the devil, who sometimes transforms into an angel of light, it must mean that the angels must have some characteristics that the devil replicates. In other words, angels have bodies, corporeal, not ghost-like. Burnet dismisses the theory which he confronted regarding the immateriality of the angel body. In the same context, Burnet suggests that the Heavens are an immensity which needs be populated. It would make no sense to have such vast territories without beings to populate them. Since angels have celestial, but corporeal, bodies, so must the resurrected as well. These bodies make up the population of the Heavens. Therefore, it would be safe to say that the resurrected bodies will inhabit a realm which requires corporeal presence and existence (Burnet 1739: 205-206).

\section{A Risen Body}

Burnet also looks at the issue of what kind of qualities will the resurrected body have. He splits them into two categories, either thick or solid, as the bodies humans have while alive, or light and transparent, as those of angels. He begins from the Bible account, namely that the celestial bodies are 'spiritual, potent, glorious, conformable to the glorious body of Christ'. Burnet's logic is quite simple since he argues that if the human body is made up of terrestrial matter, it follows that the celestial one will be made up of heavenly matter (Bush 1845: 182). Since Adam, all humankind was made up of 'dust or of terrestrial clay'. All believers are shaped in resemblance to Adam in their human bodies but are shaped in resemblance to Christ in their resurrected one. The new body is celestial, but it is still spiritual. This kind of body can be considered to be either light and thin, of the consistency of air, or vapor; or it can be thin in the sense of being made up of real particles. In either case, the resurrected body will not need any kind of sustenance, since it will not have any internal organs. This is one of the major differences between the two types of body, and Burnet has no restriction in calling the Adam-type body 'animal body'. Despite its aethereal consistency, the resurrected body is potent and active, unlike the human body, which is weak and in need of constant maintenance. Moving from one place to the other, Burnet argues, is called being active. The force the body needs to get from one place to the other, is named power. However wonderful is the human body, in all its connections and motion, it is still severely limited, in comparison with the spiritual body (Burnet 1739: 210-11). 
Any kind of body that is in motion and is connected in its parts, has no power in on itself. It is moved by some sort of 'spirituous parts', but it lacks the capacity to generate this through its own matter. In machines, all the hard parts are moved by the fluid or 'volatile' ones, yet it is all limited, since exertion on all parts is begun from one source, which is not within these components, but it is exterior to them, and controlled by the igniter. As for the human body, it is made up of parts, which are connected, and which are moved, argues Burnet, in such a way that when it is taken away, the body becomes motionless, incapable of replacing the source of the power that moves it. On the other hand, the spiritual or resurrected body will consist of 'a substance light, and vivid, and volatile'. These characteristics are connected to a fundamental characteristic in the thinking of Burnet, which should not be set aside or ignored, namely the mind. In the spiritual body, the mind seems to be the driving force, since Burnet says that the entire spiritual body would move at the desire and will of the mind. The spiritual body would have the capacity to move wherever the mind decides to take it, and it will be able to pass through other bodies, as well as rarify or condense itself. Burnet believes that a body with such capabilities, the consequence of 'the united force of the parts or particles of which such a body consists' it must be exceedingly powerful. It would be able to do whatever it wills with natural and organic bodies, as well as take down or damage any kind of matter (Burnet 1739: 211). In the end, the only element the resurrection depends on is the resurrection of Christ, and the Spirit that Christ has sent to aid the life of all believers. Since the Spirit is God, and He dwells within the body of the living believer, $\mathrm{He}$ is also the guarantee of the future resurrection. The spiritual realm that is cleaned by the presence of God in man, creates the foundation for the resurrection (The Comforter 1832: 37).

The glorified body has a certain kind of beauty, which is in tune with its glorious status. There cannot be a misshaped body in the context of a perfect world. Imperfection is a characteristic of the physical world. On the other side of this reality, in the celestial realm of heaven, all bodies will share the characteristics of perfection. Matter and the human body, in the form given while on earth cannot reach the beauty that will be given to the resurrected body. That kind of body will have a 'certain light or resulgency', which is coupled with the glory of such bodies, manifested in certain illustrious and resplendent ways. Burnet connects the prophecy in Daniel 12:2-3, with the words of Christ in Matthew 13:43, where there is a guarantee that the resurrected bodies will be part of the glory of God, which will offer light and splendor. There is no mention of any kind of shadow or darkness in the prophecies, nor in the words of Christ, with regard to the beauties of the heavens and the bodies of the believers (Burnet 1739: 213). The contrast is stark and clear, namely that no human 
physical or organic matter will reach the celestial body, thus leaving behind such characteristics. There is a trait that Burnet addresses, that might seem unimportant, but in the economy of his argument it seems to have a peculiar importance, related to the notion of beauty and light. He wonders whether the light of the bodies is their own or is it reflection of another light. He concludes that since the bodies are as that of Christ, they cannot but have their own glory, therefore their own light, therefore they are 'lucid and refulgent' (Burnet 1739: 214).

In Burnet's opinion, the most important aspect of the resurrection is the 'formation of our celestial bodies after the Glorious body of Christ'. Starting from verses such as Philippians 3:2, 1 Corinthians 15:48, Burnet describes Christ's body as one that possesses divine light, which is inherent to His body. His body, although it was scarred and broken, and suffered death, it came back to life, through Christ's own divine power, but resplendent, yet recognizable to the human mind and senses. In that resurrected body, Christ is light, just as He had at the transfiguration. He creates the light; He does not reflect it. In the same way, the resurrected bodies of the faithful will have the same virtue, but given, not earned. Christ's virtue is the cause of the divine light from within His divine being. After His resurrection, while among His disciples, He appeared in a recognizable form, although displaying supernatural powers (Bush 1845: 217). They were not aimed at humiliating or imposing fear into the disciples. In fact, Christ seemed to have used His powers to calm the disciples and show them the Jesus they had always known, with the added divine glory that they would also inherit. His powers had the ability to create the shapes familiar to the human body, yet His divine body submitted to His will only for the perception of His fellow men, not that His body would retain that particular shape for all eternity (Burnet 1739: 214-16).

In this context, there is another issue that theologians have grappled with, regarding the body of the damned. If the body of the risen Christ is perfect and the resurrected bodies of the saved are as the body of Christ, they must also be perfect. However, it seems to follow that the bodies of the damned cannot be but complete and utter contrast to the bodies of the believers. These bodies have nothing of the perfection, the light, the power, and the glory of the others. Instead they seem to have all the signs of damnation, from darkness and weakness, to the deformities inherent to the realm of the fallen. There is only ugliness and darkness in these bodies. If there is no pain in the body of the resurrected believers, there seems to be eternal pain in the others. In fact, it seems that the argument revolves around the idea of perfect opposites (de' Liguori and Jones 1836: 101).

Christ's body changed once He ascended to the heavens, since it is described in a different way in John's vision, in texts such as Revelations 
1:14 or by Daniel, in 5:5-6. The divine body of Christ is 'glorious, refulgent, flaming' in form at the Second Coming. The shape of His body and the content of His essence is not the same as the appearance He had after the resurrection. The purpose of His coming will be different, therefore the body must incorporate the essence of Christ's purpose, namely, to judge the world. If, at His first coming, He came humble and meek, and remained as such until His ascension, although at that time He was in full power and glory, at the Second Coming He will come as judge. His war will be against spiritual, as well as physical powers. His body would reflect the 'luminous and flaming majesty'. The Shekinah of God resides most resplendent in the presence of Christ, within Him, as He is the beloved Son of the Father. The issue of whether Christ's body will have flesh, as the human body, or that it would have any kind of human imperfections and wants, is clearly dismissed by Burnet, who argues that His body will be full, visible, but glorious and lacking any human 'grossness'. It seems to be an important issue in the context of the debate on the resurrection, since it is also a historical matter. The issue of Christ's body before and after the resurrection was quite ablaze in Burnet's time, since he charged the Catholics that they were misinterpreting the term sarx, to denote a metaphorical or figurative sense. For Burnet there cannot be any other meaning than physical (Burnet 1739: 220).

In the debate on the resurrection there is another issue, the intermediate state. This issue is not the subject of this essay but suffice to say that the soul seems to feel the peace of salvation or the pain of damnation. Based on various scriptures, authors such as Joseph Tracy mention that the souls of the dead are either in the presence of God, or in the presence of the hell. Either way, one will experience bliss and joy, while the other pain and retribution. However, they do acknowledge that this is not the finality for the human soul. It needs to be united with the body for the Final Judgement (Tracy 1839: 93). At that point, as it was already mentioned, opinions differ on whether the resurrected will have the same body as when they were alive, but in a glorious state, or a completely different body.

Burnet mentions several fragments of text from various sources, which note the debates regarding the body of Christ. In one of them, a dialogue between St. Austin and Consentius, the former argues that Christ had the physical body after the resurrection, but no blood. There were bones and flesh, a form and content familiar to the disciples and all who knew Him, however, there was no blood. Burnet also mentions that the debates regarding the body of Christ go deeper, but they are not helping any of the involved parties. Regardless, Burnet argues in favor of understanding that any debate must stem and 'yield to reason and Scripture' (Burnet 1739: 221). It is, therefore, necessary to understand that whatever 'flesh and 
blood' are for the human body, they are not part of the resurrected body, since there is no possible connection between that which has become sinful, and that which is glorious, without blemish, and without sin. Flesh and blood are corruptible and will stay corrupted until the resurrection. There cannot be any type of holy in the body, especially after its death, and during the putrefaction process. Spiritual beauty and holiness cannot find abode in such a context. Burnet argues that because flesh and blood are so strongly and irremediably corrupted, only an outside source of holiness can give a completely new beginning to a being that has found salvation in Christ. Burnet believes that the flesh and blood the men have before death cannot be redeemed by any kind of cleansing, since all bodies have certain proprieties, some are 'accidental and mutable', while others are 'essential and unchangeable', and when these go through changes, it will not be the body and it will not have the same structure, as before the change. A dead body will decompose, its elements will be absorbed by the ground, plants, insects, and animals. This is what Burnet argues that is the same matter but modified. The modification implies that the flesh and blood of the human body cannot turn into a glorified body, except through a new creation. The problem is, as Burnet seems to think, that there is no reason for God to modify or make incorruptible the present flesh and blood, in order to keep its appearance in the glorified body. Any kind of microscopic elements that make up the human body must be vanquished and left behind in the present body, because the glorified body keeps only a spiritual identity, not a physical identity (Burnet 1739: 223-24).

Burnet acknowledges that the power of God could, in fact, preserve the human flesh and blood, and transform them into an incorruptible matter, through His divine power. However, Burnet believes that the body will remain corruptible as long as it retains 'softness and humidity', but if it dries, much like a mummy, it will remain incompatible with the divine presence. Either way, the human body cannot dwell in the full presence of God and in His divine realm, where perfection and holiness dwell, because it is incompatible with such realms. The body is so corrupt and so fragile, that any element that it might retain, it will be destroyed in the presence of God. As Burnet concludes, the spiritual body will not consist of any 'jointed frame of bones, of flesh, and of blood, or of any of the humours or entrails of this present terrestrial body', but it will be made out of 'a more excellent matter, of a higher nature, and purity, and perfection: that I may say all in a word, it consists of matter intirely celestial, with respect both to its substance and accidents' (Burnet 1739: 226). If they are needed, as it was mentioned before, the human body, made up of its parts and microelements, will end its existence through death, either in the grave, or in some other way, or it will be changed in a split second, at the second coming of Christ. 
The resurrection does not mean that the human body will be transformed into a glorious body, but that it will retain a spiritual identity, not a bodily one. As Burnet argues, the resurrected body will have its own glory and light—a sign of divine perfection-that is not borrowed or transmitted or reflected. The glory of the resurrected body will be living and innate. The apostles saw that kind of glory at the transfiguration, and the apostle Paul witnessed it to an even greater degree on the road to Damascus. It is the same light that will be given to the glorified body, but it will remain submitted to the glory of the Son, who alone is God. Burnet underlines an interesting characteristic of Christ's human body, when he explains that Christ had always had the power of His divine being at His disposal but refrained of using it except when needed. For example, Burnet mentions the walking on water, without the light that was present at the Transfiguration, or when He was tempted, He became 'impassive', but to these one might add the instances when He fed the hungry, or healed the sick, or resurrected the dead. In none of these cases Christ revealed His glorified or celestial body. After His ascension, Burnet believes, His body has unraveled its most glorious powers, being in the full presence of God the Father, in the Heavens. Therefore, Christ's body does not retain any bones, or flesh, or blood, but it is a 'mass of liquid light, and of air that glitters with its radiancy'. It is Christ's divine dignity that is in full congruence with His celestial body.

\section{Conclusions}

For the regular Christian the doctrine of the resurrection of the body is an issue that is impossible to ignore, but which is easy to neglect. It seems impossible to consider faith in Christ without the doctrine of the resurrection. That faith needs to have a purpose and a finality beyond the realm of the physical body. That finality is eternity in a glorious body, such as the glorious body of Christ, but not equal to His. Among the theologians that worked on this doctrine, the writings of Thomas Burnet are particularly important, since he was among the first to analyze the doctrine not only from a theological and logical perspective, but also from a scientific perspective as well. His treaty on the subject of the resurrection delivers a detailed account of explanations based on biblical texts on the issue of the resurrection. His conclusions are optimistic, if not triumphalist. How could he not come to such conclusions, since the only natural result of a personal conviction on such matters is joy, hope, a closer and deeper relationship with God, one that is built in this world, but which exceeds its limits.

Burnet arrives at the conclusion that the resurrected bodies of the faithful will be as the bodies of Christ, but significantly different from the physical ones. These bodies will not have any of the physical characteristic 
of the mortal bodies. They will not have legs or hands, but they will also lack blood, flesh, and intestines. Apparently, the resurrected will know one another, but they will not think in the same way as while in the human body.

Burnet's work is important because it adds to the existing voice on the matter, thus creating a better understanding of the doctrine of resurrection, by offering a window into the kind of debates that were important in the 17 th century. His capacity to combine theology with scientific methods of reasoning prove that Christianity had outgrown the idea of the religion of the poor. The church had always bright and educated scholars, but Burnet's book offers an important perspective on the logic behind the doctrine of the resurrection.

\section{Bibliography}

Blomfield CJ (1828) Twelve Lectures on the Acts of the Apostles: Delivered on the Wednesdays during Lent in the Years 1827, 1828. London: B. Fellowes. http://archive.org/details/12LecturesOnTheActsOfTheApostles.

Bold S (1706) A Discourse Concerning the Resurrection of the Same Body, with Two Letters Concerning the Necessary Immateriality of Created Thinking Substance. A Collection of Tracts, Publish'd in Vindication of Mr. Lock's Reasonableness of Christianity, as Deliver'd in the Scriptures; and of His Essay, Concerning Humane Understanding. London: A and J Churchill. http://archive.org/details/collectionoftrac00bold.

Burnet T (1739) A Treatise Concerning the State of the Departed Souls, before, and at, and after the Resurrection. London: Red-Lyon in Pater Noster Row.

Bush G (1845) Anastasis; or The Doctrine of the Resurrection of the Body, Rationally and Scripturally Considered. http://archive.org/details/anastasisordoct01bushgoog.

de' Liguori AM, and Jones J (1836) The Way of Salvation: Meditations for Every Day of the Year. London: Keating \& Brown. http://archive.org/details/TheWayOfSalvation.

Drew S (1811) An Essay on the Identity and General Resurrection of the Human Body. Brooklyn: T. Kirk. http://archive.org/details/essayonidentityg01drew.

Felton H (1725) The Resurrection of the Same Numerical Body, and Its Reunion to the Same Soul: Asserted in a Sermon Preached before the University of Oxford, at St. Mary's on Easter-Monday, 1725 in Which Mr. Lock's Notions of Personality and Identity Are Confuted and the Author of the Naked Gospel Is Answered. London: Printed at the Theatre, and are to be sold by Steph. Fletcher, and Rich Clements Booksellers in Oxford and Benj. Motte Bookseller near the Middle Temple-Gate in London. http://archive.org/details/resurrectionofsa00feltuoft. 
Stanhope Smith S (1809) The Resurrection of the Body: A Discourse Delivered in the Presbyterian Church in Georgetown, on Sun., Oct. 22, 1809. Washington: [s.n.]. http://archive.org/details/resurrectionofbo12smit.

*** (1832) The Comforter; or, Extracts Selected for the Consolation of Mourners under the Bereavement of Friends and Relations. New York, NY: J\&J Harper. http://archive.org/details/TheComforterOr.

Tracy J (1839) The Three Last Things: The Resurrection of the Body, the Day of Judgment, and Final Retribution. Boston, MA: Crocker \& Brewster. http://archive.org/details/threelastthingsr00tracrich. 